\title{
DAVORIN JENKO AND THE CULTURAL LIFE OF SLOVENES AND SERBS IN THE SECOND HALF OF THE $19^{\text {TH }}$ CENTURY
}

\author{
UDC 78.071.1:929 D.Jenko
}

\begin{abstract}
Gregor Jenuš
Ministry of Culture, Archives of the Republic of Slovenia, Ljubljana, Slovenia

Abstract. Davorin Jenko was a choirmaster, conductor, musical tutor as well as, for almost half a century, a composer. Therefore, his life should be evaluated as marked by pedagogical and cultural-artistic work, and a fight for the national revival of Slovenes and Serbs within the Pan-Slavic movement. Ethnic relations in the romantic and postromantic era were extremely tense. At the same time, that was an exceedingly important time for the Slovenes and the Serbs, a time that brought about cultural renaissance and development. In the late 19th century Jenko became one of the first representatives of the Romantic Era of Slovenian and late Serbian music. Despite his exceptional role in this cultural renaissance, during his lifetime he hasn't received a proper place or honors in Slovenia. It was the Serbs who honored Jenko with full membership in the Serbian Royal Academy.
\end{abstract}

Key words: Davorin Jenko, Naprej, zastava Slave!, Bože pravde, post-romanticism, national revival

\section{INTRODUCTION}

Davorin Jenko was born in the village of Dvorje in Upper Carniola, at that time a part of the Austrian Empire. Because of his many fields of work his life has to be considered with regard to several aspects. He was a choirmaster, conductor, musical tutor and, for almost half a century, a composer. His life was marked by pedagogical and culturalartistic work, as well as a fight for national revival of Slovenes and Serbs within the PanSlavic movement. The ethnic relations in the romantic and post-romantic era in the Austrian Empire (especially during the period that followed the March Revolution and Bach's absolutism) were extremely tense. The dominant German (Austrian) culture considered the Slavic national movement a huge threat hence they tried to suppress its development. At the same time, it was an exceedingly important historical period for

Received September 30, 2016 / Accepted November 17, 2016

Corresponding author: Gregor Jenuš

Ministry of Culture, Archives of the Republic of Slovenia, Ljubljana, Slovenia

E-mail: gregor.jenus@gov.si 
Slovenes and Serbs, a period that brought about cultural renaissance and development. By his outstanding work in the late $19^{\text {th }}$ century, Jenko became one of the most important representatives of the Romantic Era of Slovenian and late Serbian music.

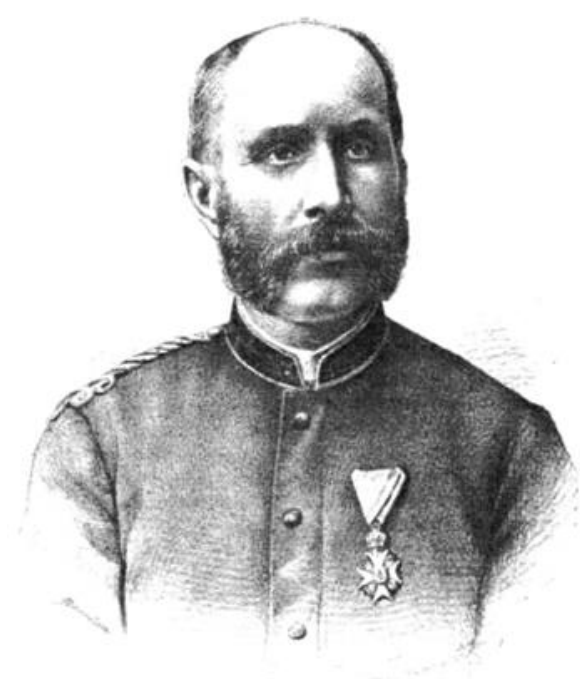

Fig 1 Picture of Davorin Jenko published in Slovan, May 15, 1885, Nr. 10, 147 [1], on the occasion of the $25^{\text {th }}$ anniversary of Naprej zastava, Slave!

\section{JENKO'S YOUTH AND EDUCATION}

Davorin Jenko was born on November $9^{\text {th }}, 1835$ in the village of Dvorje in Upper Carniola (at that time part of the Austrian Empire) son of a wealthy farmer Andrej and mother Marija, born Kepic. On his birth he was given the name Martin, a name that later, because of the influence of the Pan-Slavic movement, was changed to Davorin.

He attended primary school in Cerklje and at the age of eight, he was transferred to secondary school (Realschule) in Kranj (Mahkota 1934, 3-4; Cvetko 1955, 21-22; 1981, 10-11; Jenuš \& Križnar 2015, 7-9, 22-25). ${ }^{1}$ Jenko grew up in the period of the March Revolution and Bach's absolutism, a time of no support for the Slovenian national movement and of suppressing Slovenian national ideas and ideals. The whole political and educational system worked in favor of German culture. The German (Austrian) conservatism and nationalism could, for example, be found in the Austrian educational system that privileged the German language. The youth were exposed to Germanisation from a very early age in schools and assimilated into German culture. Therefore, the Slovenian national movement was limited to a relatively small circle of intellectuals, who, because of the way the Austrian educational system worked, got their higher education degrees in Austrian, Italian or Czech universities (Vodopivec 2007, 10). Until the collapse of the Austrian Empire in 1918 the Austrian authorities prevented the establishment of a university in Ljubljana.

\footnotetext{
${ }^{1}$ See also: Davorin Jenko. Slovan, May 15 1885, Nr. 10, 147 [1].
} 
In 1848 Jenko was admitted to the gymnasium in Ljubljana. ${ }^{2}$ Initially it appeared that Jenko wouldn't have any difficulties in graduating. He was among the best students in his class, but this changed after 1850, when Jenko entered his third year in the gymnasium and his teachers started to state that he was undoubtedly "\%.../ a very capable student, able of even better results, if he would be studying harder" (Cvetko 1955, 40). While it is certain that his parents wanted that their son to receive the best possible education, Jenko's laziness became an obstacle, at least in the early years. Cvetko states that in the later years of gymnasium (from the fifth grade onwards) it wasn't just his 'artistic spirit' that hindered Jenko`s progress in classes, but also his ethnicity. A major role in Jenko's 'defeat' was a professor of Greek at the higher gymnasium in Ljubljana, Anton Globočnik (Globozhnik), who apparently was a 'fanatical' supporter of Bach's absolutism and its movement against national revival. After two successive failures in the fifth grade the question arose for Jenko: What am I to do? (Cvetko 1955, 26-27).

Taking into consideration the educational system in the Slovenian lands, Jenko had to say goodbye to Ljubljana and try his luck in Trieste. Although it is difficult to confirm whether Globočniks attitude towards the Slovene students actually played any role in Jenkov`s failure in Ljubljana, it is necessary to state that he completed his fifth grade of higher gymnasium in Trieste without any difficulty despite the fact that he had to get used to the new environment and the Italian language. Life in Trieste was very important and beneficial for Jenko not only in terms of his studies and music, which undoubtedly developed, but more importantly in terms of his perception of ethnic or national rights and coexistence of different cultures. Trieste after all was a cosmopolite center of the Austrian Empire. In 1858 Jenko, at that time already twenty years old, finally completed the gymnasium in Trieste successfully and was ready to move on (Cvetko 1955, 26-27; 1981, 12; Jenuš \& Križnar 2015, 24).

\section{VIENNA AND THE SLOVENIAN SINGING SOCIETY}

After graduating from Trieste in 1858, Jenko traveled to Vienna to study law. This certainly wasn't his choice, but a wish/demand of his father's (Prelić 2010, 241-242). Regardless of whether Jenko wanted to study law or not, after Trieste, Vienna was a very important experience. Even before the collapse of Bach's absolutism, Vienna became a meeting point for academics, intellectuals and an important center of nationalistic movements of Slavs in the Austrian Empire. (Cvetko 1955, 30-32; 1981, 15; Jenuš \& Križnar 2015, 25). Owing to their small numbers and under the influence of the 'young Czech' movement (Mladočeši) the Slovene intellectuals started to join Slavic literary and cultural societies as well as café circles. One of those intellectuals was Davorin Jenko. This national, political and cultural atmosphere that prevailed in Vienna, was highly encouraging for Jenko (Sandić 1885, 256 [14]). He joined a circle of nationally conscious Slovenian students, among whom Josip Stritar, Fran Erjavec and Valentin Zarnik stood out. The members of the circle were not strangers to Jenko, and they were frequently

\footnotetext{
${ }^{2}$ Until an educational reform in 1849, the Slovenian territories within the Austrian Empire had 11 gymnasiums, and 3 lyzeums (Hochschule) in Ljubljana, Klagenfurt and Gorizia that allowed a study of theology of philosophy (Vodopivec 2007, 10; Jenuš \& Križnar 2015, 23).
} 
accompanied by the Slovenian poet and writer Simon Jenko (Cvetko 1955, 31; 1981, 15; Križnar 1995, 221; Jenuš \& Križnar 2015, 25).

In Septemer 1885 the Slovenian newspaper Slovan wrote:

"[...] during that time two Slovenians brothers attended university in Vienna: Simon and Davorin Jenko. The first was a poet, the second a musician [...] Both were gifted student, but they were poor; Simon was a teacher to Dušan and Milica, son and daughter of Peter Preradović [general in Austro-Hungarian army of Croatian descent, authors note], Davorin, was a music teacher" (Sandić 1885, 256 [14]).

The author of this article, Aleksander Sandić, didn't know that, in fact, Davorin and Simon Jenko were not brothers. Still, they knew each other. Simon and Davorin met during their stay at the secondary school in Kranj. Although it is not clear if Martin was a patriot and supporter of the Pan-Slavic movement prior to his life in Vienna, it is certain that he became one during his studies. Under the influence of the Pan-Slavic movement and Croatian Illyrism he changed his name from 'Martin' to 'Davorin' (Cvetko 1955, 30 $31 ; 1981,19)$.

The circle of nationally conscious Slovenian students in Vienna did not consider Jenko just a sympathizer and a pleasant companion, but an especially talented musician who could help them in achieving their goals. They needed a talented musician who would be able to lead a choir and compose music for their patriotic texts. It is clear that, by that time, Jenko was much more committed to his music than to his studies (Jenuš \& Križnar 2015, 25).

"[...] the talent of singing is a God given gift. Whoever has it has to be thankful. A beautiful song, sad or happy, beautifully sang, can touch your heart; a song with which a mother swings her baby to sleep, and a song that inspires soldiers going in to a bloody fight.

Individual people, as well as different nations, haven't equally received this divine gift. Slovenes, that may be said, like to sing and they do it beautifully, like only a few nations can [...] Slovenes don't sing only at home; the joy of singing accompanies them in distant countries and presents a bond with their beloved homeland among foreign people," wrote writer Josip Stritar in 1906 about the connection of Slovenes to their music (Stritar, 1906).

The circle of nationally conscious Slovenian students in Vienna trusted Davorin Jenko with the task of setting up a Slovenian choir. They expected that, although his musical skills were more or less self-taught, Jenko would build on the enthusiasm of his colleagues and guide them as a choirmaster. According to Sitar this wasn't the first attempt in Vienna to establish a Slovenian choir. Apparently one had existed at the beginning of the second half of the 19th century, but it was more of a sporadically 'ensemble' of enthusiasts that sang in a tavern in the Viennese district next to the Church of St. Paul rather than a 'semiprofessional' choir. "[...] this singing was a divine service for us; we sang so that the angels would listen to us" (Stritar, 1906).

However, this 'choir' was more of a side effect of drinking and socializing youth than a systematic attempt to sing Slovenian or patriotic songs. These informal singing gatherings prompted Jenko to try to establish a permanent choir. With the help of Valentint Zarnik, who was respected and popular among the Viennese students and also a skillful organizer, Jenko established the Slovenian Singing Society (Slovensko pevsko društvo) in 1859. He became its first artistic leader. Slovenian publicist and editor Fran 
Rakuša said that the 'society' had its meetings in various taverns and singing halls such as Zum goldenen Sieb or Zum Lothringer (Rakuša 1890, 157).

Because of its choir, the Slovenian Singing Society quickly gained a positive reputation and a broader meaning in the Slavic community, when students of other Slavic nationalities - mainly Serbs, Croats and Bulgarians - began to join in. This strengthened the contacts between Slavic students in Vienna and transformed the Slovenian Singing Society into an important meeting point of the Pan-Slavic movement (Sandić 1885, 255 [13]).

The Serbs for example were represented by Aleksander Sandić, at that time the editor of the newspaper Ost und West. Sandić, who later became a professor of Old Slavic language and literature in Novi Sad, wrote down his memories about his time in Vienna in 1885 and published them in the newspaper Slovan:

"[...] there was an incredible life force among the Slavic youth in Vienna that was unprecedented among the Slavs" (Sandić 1885, 255 [13]).

'Besede' (translated as 'wards' - describes gatherings with discussions, singing and reading, author's note) became a meeting point for the Viennese Slavs and received a cultural and political background. The choir of the Slovenian Singing Society became a core part of the Slavic national movement. Jenko raised the quality of the choir and at the same time developed his own skills in composing choral music. At the beginning of the second half of the 19th century original Slovene choral music was still in its infancy. Musical compositions were rare and modest. Despite some compositions of the Croat Vatroslav Lisinski, Jenko had a limited repertoire. This put him in a position where he had to become a composer himself. The choir of the Slovenian Singing Society therefore became Jenko's first real music school where he learned the demands of vocal sentences, the specifics of interpretation and compositional patterns. Jenkos compositional efforts proved to be successful. He composed the songs Pobratima and Mornar, and performed them together with 'his' choir on various 'words' across Vienna. By the end of 1860 Jenko had accumulated so many songs, that he decided to publish them in a booklet titled Opus I. Jenko announced this success to the editor of Slovenian newspaper Slovenski glasnik (The Slovene Herald) Anton Janežić in 1861 and dedicated the booklet to Josip Strossmayer "[...] the founder of the Yugoslav academy". Jenko's Opus I, contained only twelve songs with texts by France Prešeren, Fran Levstik, Miroslav Vilhar, Lovro Toman, France Cegnar and Simon Jenko. Among the songs one can find Prešerens Strunam or Vilhars Lipa, as well as a song that placed Jenko in the history of music, the Slovene anthem Napej, zastava slave! (Forward, flag of glory!) (Mahkota 1935, 8; Cvetko 1955, 57; 1981, 34; Smrekar 2006, 58).

In May 1860, only twenty-five years old, in the spirit of national enthusiasm Davorin Jenko composed the Slovenian national anthem, which overnight became a symbol of the national struggle of Slovene people and 'catapulted' Jenko to the top of the Slovene late romanticism. The lyrics were originally written by his friend and fellow Simon Jenko and then improved collaboratively by both. The poem was first publicly sung with great success in front of a large Slavic audience on October $22^{\text {nd }}, 1860$, and was first published in the newspaper Slovenski glasnik on December 1st, 1860 (Jenuš \& Križnar 2015, 27$28)^{3}$

\footnotetext{
${ }^{3}$ In 1885 it became the first poem in Slovene to have been translated into English, under the title With Slava's Banner, Forward! The translators were Andrej Jurtela, the first lecturer of Slavic languages at the University of Oxford, and English journalist Alfred Lloyd Hardy, who had a keen interest in music and in Slavic culture (Jenuš \& Križnar 2015, 27-28)
} 


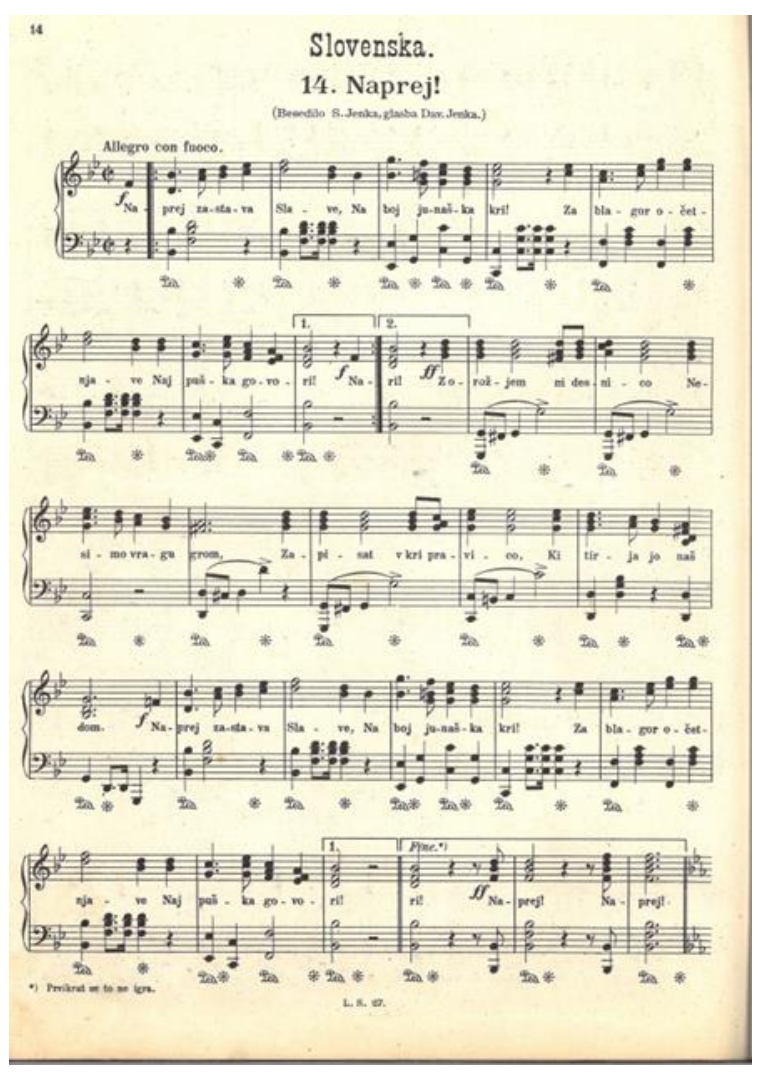

Fig. 2 Davorin Jenko: Slovenian anthem Naprej, zastava slave! Text written by Simon Jenko, arr. for piano by Franc Gerbič. Franc Gerbič: Slovanske himne za glasovir. Ljubljana 1907, 14.

Dragutin Cvetko called Jenkos song Napej, zastava slave! the "[...] Slovenian Mareillaise" since it had an outstanding revolutionary spirit and it tells the story of a boy who goes to defend his homeland despite the fact that his mother asked him to stay. As such, it was a patriotic recruiting poem and became a part of nearly every repertoire of Slavic choirs at the end of the $19^{\text {th }}$ century (Cvetko 1955, 60).

Jenkos success with Napej, zastava slave! earned him recognition even among conservative circles (such as the so called 'Old Slovenes) other Slavic groups, but it couldn't stop the downfall of the Slovenian Singing Society. The expansion of the PanSlavic movement demanded a high price. The in 1862 in Vienna established Slavic Singing Society. It became a serious competitor and caused many Slovene, Croat and Serbian intellectuals to join them. By doing so they unintentionally destroyed their own society (Cvetko 1955, 60; Jenuš \& Križnar 2015, 29).

In 1862 Jenko was left empty-handed. He couldn't find a place in any choir in Vienna, and because of his 'investment' into music, he had not completed his law studies. Despite his 'fame' as a composer of one of the most important hymns of his time, he couldn't get 
a position in the Slovenian lands. Actually, his fame was an obstacle. Because he was a member of the progressive 'Young Slovene' movement, the conservative 'Old Slovenes', under the leadership of Janez Bleiweiss, denied him any help (Cvetko 1955, 61-63).

In the hour of need an offer from the Serbian Ortodox Church Comunity (Srpska crkvena opština) from Pančevo changed Jenkos life. The choir of the Serbian Church Choral Society of Pančevo (Pančevačko srpsko crkveno pevačko društvo) was looking for a choirmaster and singing teacher that would contribute to the development of choral church singing in this city of Vojvodina. Recommended by Joseph Hellmesberger, the then artistic director of the Association of music lovers in Vienna (Geselschaft der Musikfreunde Wien) and headmaster of the music conservatory, Davorin Jenko was offered a contract by the city. Hellenberger considered Jenko a very promising young conductor and, at that time, Serbian music needed someone like him (Cvetko 1955, 121124; 1981, 88-94; Jenuš \& Križnar 2015, 29). In 1862 Jenko became a conductor of the harmonic choral church and a singing teacher for the Serbian youth at the Secondary School in Pančevo. In addition to his work as a choirmaster and teacher, he started to compose music for various 'wards' of the singing society in Pančevo. The resulting compositions (Sabljo moja, dimiskijo, Bogovi silni, Što ćutiš Srbine, tužni) quickly became very popular among the public and spread Jenkos reputation outside the borders of Pančevo. The success in Pančevo brought him new opportunities and contracts. For example, the newspaper Danica writes that Jenko arranged two 'wards' in Novi Sad in 1864, which experienced a very positive response of the public. This was very important for Jenko since Novi Sad was establishing itself as a new cultural center in Serbia. Although at first the positive feedback for Jenko's work was good for the reputation of the Serbian Church Choral Society of Pančevo, it soon started to be a problem. Jenko was getting sloppy. He ignored his obligations. He was frequently late to work, or didn't show up at all. It also often happened that Jenko, without noticing his employer, led other choirs, about which his superiors found out from the media (Cvetko 1955, 111-113; 1981, 78-86).

The leaders of the singing society in Pančevo were in a dilemma. Their choirmaster undoubtedly changed the quality of music and singing in Pančevo, but they simply couldn't allow Jenko to break the rules of his contract. So, when they were negotiating a new contract in the second half of 1864, they offered Jenko more money and a greater artistic freedom. However, the contract with Jenko was not signed. (Cvetko 1955, 111113). The health of famous Serbian musician and composer Kornelije Stanković deteriorated. Due to his health Stanković, who was one of the most important Serbian musicians of the romantic era, couldn't lead the Belgrade Singing Society (Beogradsko pevačko društvo) anymore. So he suggested that the society should contact Davorin Jenko, with whom he worked on 'wards' in Pančevo and Novi Sad. ${ }^{4}$ He considered Jenko as a very talented composer and conductor that was already widely recognized in Serbia (Cvetko 1955, 111, 121-123; 1981, 90-91).

Jenko started his negotiations with the Belgrade Singing Society and on September $4^{\text {th }}$, 1865 signed a one-year contact. Cvetko states that Jenko became a conductor as well as a singing teacher for the choir in Belgrade. Although it seems that Jenko had outgrown the position of a singing teacher, he undoubtedly had many experiences in that field of work.

\footnotetext{
${ }^{4}$ Archives of Serbia (hereinafter: AS), PO box 107/70, Appeal from Davorin Jenko to Kornelije Stanković asking him if he could send his compositions for a concert in the Church in Pančevo. April 14th, 1863.
} 
Even more important, this position opened the doors to the Serbian capital, and thus into the heart of the Serbian cultural life (Cvetko 1955, 111, 121-123; 1981, 90-91; Stojković 1979, 286; Vasić 2009, 383-384).

The development of national, political and economic life in Serbia in the second half of the $19^{\text {th }}$ century had a direct impact on the expansion in arts and humanities. Serbia was flourishing in the fields of scientific, artistic and academic life. In order to bring Belgrade closer to other European capital cities of the time gradually a need to establish a modern theater occurred. A special committee was formed in 1868 with the task to establish the National Theater, which came to life on October 30th, 1869 (Cvetko 1955, 179-180).

During that period Jenko spent some time in Prague, where he studied composition, instrumental music (etc.), so that he could increase his artistic knowledge. Despite his efforts and the fact that the Belgrade Singing Society gave its blessing for his off time in Prague and could benefit from his newly found experiences, the relationship between the superiors of the society and Jenko was not good. It constantly came to disagreements and in 1870 Jenko did not prolong his contract and decided to leave. ${ }^{5}$

Under the circumstances, in 1870, Jenko received an offer from the newly formed National Theatre in Beograd (Narodno pozorište $u$ Beogradu). Unlike in his past experiences, when Jenko seemingly couldn't stay in one position for too long, he finally found his place. He became a conductor and singing teacher in the national theater and remained loyal to this institution until his retirement in 1902. The national theater was a new challenge for Jenko. Its repertoire consisted of serious Serbian literature for which Jenko composed music, foreplays and additional songs (Jenuš \& Križnar 2015, 27-28, 98, 100; Turlakov 1994, 13-14).

Jenko`s new found success in Belgrade echoed in the Slovenian lands. Slovenian writer, poet and first aesthetics critic Josip Stritar wrote in the newspaper Zvon in 1870:

"[...] do we have men capable of elevating the quality and level of (Slovenian, authors note) national music? Where is the much celebrated and famous composer of the worldwide known song 'Naprej', who is without a doubt the most brilliant Slovenian composer? Certainly he has been sent [...] to Prague to finish his musical studies; has been granted a proper position so he can live without distress and devote himself to his artistry and conduct music where and whenever he wants!

You're wrong, curious stranger! The man, of whom you speak, isn't at the place where he could work in favor and honor of his nation! He is struggling out in the world and is currently living faraway in the 'White Town' (Beograd, authors note), where they know how to appreciate his work. Why couldn't he arrange (the original text reads give, authors note) a 'ward' in the middle of the Slovenian lands? Just his name would have been enough; everyone would have come to listen, gentlemen would not have asked how much the entrance fee is" (Stritar 1870, 387 [19]).

Although Stritars evaluation of Jenko`s work and his importance for the Slovenian music and culture seamed harsh at first glance, it was a reflection of the existing reality, especially if we consider the possible loss for the Slovenian nation and culture. With every musical piece that Jenko composed or collaborated to he showed his opponents how wrong they were when they denied him assistance.

${ }^{5}$ AS, PO box 60/121, Invitation of the Belgrade Singing Society to Jovan Boškovic to a 'word' in honor of the departure of Davorin Jenko. October 4th, 1869. 
In 1872 Jenko demonstrated his remarkable talent again. He composed the music for Jovan Đorđevićs drama Markova sablja (Markos saber), a very emotional play that reaches its climax in the song Bože pravde (God of Justice). This song enjoyed an unprecedented popularity among the public and it soon became Serbia's national anthem Jenuš \& Križnar 2015, 36, 100-103; Petrović, 1993, 41).

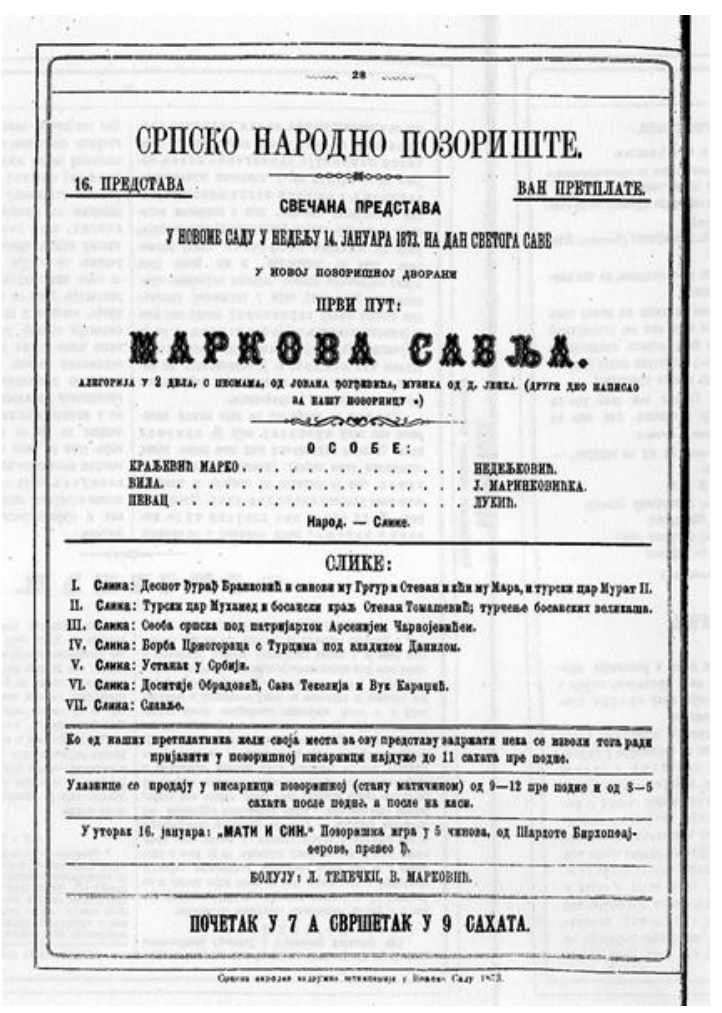

Fig 3 A flyer of the first performance of the stage play Markos sabre in Novi Sad on St. Sava's Day, January 14 1873. Pozorište, Novi Sad, II, Nr. 7, January 14, 1873, 28.

It is remarkable that Jenko composed the music for two Slavic national anthems - the Slovenian and the Serbian - and contributed to the development of both, the Slovenian and the Serbian culture. With his musical contribution to operas, stage plays, choirs, he became one of the most recognizable representatives of Slovenian and Serbian romanticism. Therefore, the Serbian Royal Academy in 1888 honored Jenko with full membership (Cvetko 1955, 121-124; 1981, 90-94).

Ana Matović wrote about Jenko: “[...] He was Slovenian by his descent and origin, but lived more than half a century in Pančevo and Beograd. Davorin Jenko was one of our most 'fruitful' composers for theater of all time - industrious like an ant. One can fearlessly call him the reformer of music and stage play in Serbia - not in context of the development in culture in the world during that time, but in context of what awaited him when he came in to the National theater and what he left behind [...]" (Matović 1997, 349). 
After retiring from the Belgrade National Theater in March 1902 Jenko withdrew from public life. Until his death in 1908, Jenko lived with Vela Nigrinova in a house in Belgrade and frequently visited his 'first home'. When she died, it seems that Jenko lost his soul mate. They didn't have any children and so Jenko left Belgrade in 1910 and returned to Ljubljana where he died in November 1914 - just at the brink of war that wouldn't have left him untouched (Cvetko 1955, 275).

"As he loved his 'old homeland', he remained committed to his 'new homeland', which has not only left a mark on his artistry, but also to his personality. He was a Slovene and a Serb, a Slavic person in one and the same person, full of enthusiasm and belief until the end of his life" (Cvetko 1955, 275).

\section{REFERENCES}

Anonim. (1885). Davorin Jenko. Slovan, May 15, Nr. 10, 147-148 [1-2]

Cvetko. D. (1955). Davorin Jenko. Doba - življenje - delo. Ljubljana: Slovenski knjižni zavod

Cvetko. D. (1980). Davorin Jenko. Ljubljana: Partizanska knjiga

Jenuš. G., F. Križnar. (Ed.). (2015). Davorin Jenko 1835-1914. Ljubljana: Arhiv Republike Slovenije

Mahkota. K. (Ed.). (1935). Davorin Jenko. Ljubljana: Založba Glazbene matice

Matović. A. (1997). Uloga Davorina Jenka u formiranju srpskog nacionalnog muzičkog pozorišta. In S. Rajičić (Ed.), 125 godina Narodnog pozorišta u Beogradu - Naučni skup povodom jubileja najstarijeg beogradskog teatra (1686-1993). Beograd: SANU

Petrović. Ž. (1993). Repertoar Narodnog pozorišta u Beogradu 1868-1914 - jubilarno izdanje povodom 125 godišnjice osnivanja Narodnog pozorišta u Beogradu (1886-1993). Beograd: Muzej pozorišne umetnosti Srbije

Prelić. M. (2010). Kako pamtimo Davorina Jenka. Traditiones, 39/1, 239-259.

Rakuša. F. (1890). Slovensko petje v preteklih dobah. Drobtinice za zgodovino slovenskega petja. Ljubljana: Narodna tiskarna

Sandić. A. (1885). K petindvajsetletnici Davorina Jenka skladbe 'Naprej zastava Slave! Slovan, September 1, Nr. $17,255-256$ [13-14].

Smrekar. B. (2006). Prispevek Davorina Jenka k slovenskemu samospevu. Muzikološki zbornik, vol. 42, Nr. 2, $57-63$.

Stojković. B. (1979). Istorija srpskog pozorišta od srednjeg veka do modernog doba (drama i opera). Beograd: Muzej pozorišne umetnosti Srbije.

Stritar. J. (1870). Glasba. Zvon. Lepoznanski list, December 15, Nr. 24, 385-387 [17-19].

Stritar. J. (1906). Lešniki. Knjiga za odraslo mladino. Klagenfurt. Online: http://sl.wikisource.org/wiki/Le\% C5\%A1niki,_1906\#12._Na.C5.A1e_petje

Turlakov. S. (1994). Letopis muzičkog života u Beogradu 1840-1941. Beograd: Muzej pozorišne umetnosti

Vasić. A. (2009). Davorin Jenko, In Č. Popov (Ed.), Srpski biografski rečnik, knj. 4. Novi Sad: Matica srpska: 383-384.

Vodopivec. P. (2007). Kulturno-duhovne razmere na Slovenskem v 19. stoletju. Bogoslovni vestnik, Nr. 1, 10.

\section{Archival records:}

Archives of Serbia, PO box 107/70, Appeal from Davorin Jenko to Kornelije Stanković asking him if he could send his compositions for a concert in the church in Pančevo. April 14th, 1863.

Archives of Serbia, PO box 60/121, Invitation of the Belgrade Singing Society to Jovan Bošković to a 'word' in honor of the departure of Davorin Jenko. October 4th, 1869. 


\section{DAVORIN JENKO I KULTURNI ŽIVOT SLOVENACA I SRBA U DRUGOJ POLOVINI XIX VEKA}

Davorin Jenko je bio horovođa, dirigent, muzički pedagog i gotovo pola veka bavio se komponovanjem. Zbog toga je njegov život u ovom radu analiziran kroz nekoliko aspekata. On je obeležen pedagoškim i kulturno-umetničkim radom kao i borbom za nacionalni preporod Slovenaca $i$ Srba u okviru sveslovenskog pokreta. Nacionalni odnosi u romantičarskom i poznoromantičarskom periodu bili su veoma napeti. Istovremeno, to je kako za Slovence tako i za Srbe bio veoma značajan period tokom kojeg su doživeli kulturni preporod i razvoj. Krajem XIX veka Jenko je postao jedan od prvih predstavnika romantizma u slovenačkoj, a kasnije i srpskoj muzici. Uprkos njegovoj izuzetnoj ulozi u kulturnom preporodu, Jenko za vreme svog života u Sloveniji nije dobio adekvatano priznanje. Za razliku od Slovenije, Jenku je u Srbiji ukazana čast članstvom u Srpskoj kraljevskoj akademiji.

Ključne reči: Davorin Jenko, 'Naprej, zastava slave!', 'Bože pravde', pozni romantizam, nacinalni preporod 